\title{
Inhibin- $\alpha$ subunit expression in uterine endometrioid adenocarcinomas and endometrial cancer cell lines: a potential prognostic factor
}

\author{
IOANNIS MYLONAS \\ First Department of Obstetrics and Gynecology, Ludwig-Maximilians-University Munich, Munich, Germany
}

Received August 27, 2010; Accepted November 2, 2010

DOI: $10.3892 /$ ijmm.2010.586

\begin{abstract}
Inhibins/activins are secreted polypeptides of the transforming growth factor- $\beta$ superfamily, forming a family of dimeric, disulphide-linked proteins. Inhibins are composed of an $\alpha$-subunit and one of two possible $\beta$-subunits. Both inhibins and activins have substantial roles in human reproduction and in endocrine-responsive tumors. However, the prognostic significance and clinical implications of the inhibin- $\alpha$ subunits in uterine endometrioid adenocarcinomas is still not clearly defined. A series of 231 uterine endometrioid adenocarcinomas of a previous well-characterized cohort were re-evaluated for the expression of the inhibin- $\alpha$ subunit and correlated with several clinicopathological characteristics and clinical outcome. Additionally, several endometrial epithelial cell lines (Ishikawa plus and minus, HEC-1A, HEC-1B and RL95-2) were analyzed for the expression of this subunit using immunohistochemical and molecular biological techniques. A significant association between the inhibin- $\alpha$ subunit and histological grade, surgical staging and myometrial invasion was demonstrated. Survival analysis demonstrated that inhibin- $\alpha$ immunoreactivity significantly affected progression-free, cause-specific and overall survival of patients with endometrioid adenocarcinomas. The analyzed endometrial cancer cell lines can also synthesize this subunit. Inhibin- $\alpha$ seems to have a substantial role in the carcinogenesis and pathology of uterine endometrioid carcinomas, and might be used as a marker to identify highrisk patients and may aid in the selection of patients for a more aggressive adjuvant therapy. Since uterine cancer cell lines express the inhibin- $\alpha$ subunit, they constitute adequate in vitro models for assessing its function in endometrial carcinogenesis. However, further research is warranted to elucidate the possible implications of inhibin- $\alpha$ in endometrial carcinogenesis.
\end{abstract}

Correspondence to: Dr Ioannis Mylonas, First Department of Obstetrics and Gynecology, Ludwig-Maximilians-University Munich, Maistrasse 11, D-80337 Munich, Germany E-mail: ioannis.mylonas@med.uni-muenchen.de

Key words: endometrioid adenocarcinoma, cancer cell lines, inhibin- $\alpha$, prognosis, survival

\section{Introduction}

Uterine cancer has become the most frequent gynecologic malignancy in the Western world (1-3). Meanwhile, endometrial cancer has been classified in two different clinicopathological categories according to several biological and molecular characteristics $(2,4-6)$. Type I endometrial cancers account for almost $80 \%$ of endometrial cancers, being mostly endometrioid adenocarcinomas with low histological differentiation and a more favorable outcome compared to Type II endometrial cancers (1-5,7). Although several prognostic factors have been established $(1,2)$, it is assumed that approximately $20 \%$ of these patients die due to their disease (3). This is actually an unusual situation for a solid tumor, especially since patients with endometrial cancer are diagnosed in an early stage.

Inhibins are heterodimers that consist of an $\alpha$-subunit and one of two possible $\beta$-subunits ( $B A$ or $\beta B$ ) linked by disulphide bonds, whereas activins are homodimers of $B$-subunits (8-10). Inhibins and activins are secreted polypeptides of the transforming growth factor- $\beta$ (TGF- $\beta$ ) superfamily (8-10). The TGF- $\beta$ proteins have been recognized as important regulators in human reproduction $(11,12)$ and carcinogenesis $(13,14)$. Moreover, TGF- $\beta$ is thought to act as a tumor suppressor in premalignant stages of carcinogenesis with an additional role as a pro-oncogene in later stages of the disease, leading to metastasis (15). In this context, the $B$-subunit has been identified as a tumor suppressor that was first observed after functional deletion of the inhibin- $\alpha$ gene in mice $(16,17)$. These knock-out mice presented with ovarian granulosa cell tumors of high penetrance, leading to high lethality $(16,17)$. Even when the pups were ovariectomized after birth, they developed adrenocortical tumors $(16,17)$.

The primary roles of inhibin/activin have been defined in the modulation of FSH production (18), exerting a substantial function as endocrine regulators of the human reproductive endocrine axis. Additionally, they have also been detected in endocrine tumors (19), including ovarian (19-21), endometrial (22-26) and breast cancer tissue $(27,28)$. Moreover, their differential expression has suggested an important role in malignant cell transformation $(19,22,23,25)$. The inhibin- $\alpha$ subunit was recently demonstrated to be an independent prognostic parameter in a large cohort analysis of 302 human endometrial carcinomas (23). However, a re-evaluation of the inhibin- $\alpha$ subunit in uterine non-endometrioid carcinomas 
revealed no better survival (29). Therefore, it is inferred that inhibin- $\alpha$ might only be a significant prognostic marker in endometrioid adenocarcinomas. However, the precise prognostic significance and clinical implications of the inhibin- $\alpha$ subunit in endometrioid adenocarcinomas have not yet been completely elucidated. Since the inhibin- $\alpha$ subunit might have a high clinical relevancy in endometrial cancer, an understanding of the molecular mechanisms underlying the synthesis and regulation of inhibins and activins in this tumor type is warranted. Human endometrial epithelial cancer cell lines are good in vitro models for studying carcinogenesis. The phenotypic characteristics of these endometrial epithelial cell lines differ markedly, so the knowledge of the expression patterns of inhibin- $\alpha$ synthesis in these cells is necessary for studying specific pathways regarding carcinogenesis.

Therefore, aims of this analysis were the re-evaluation of the inhibin- $\alpha$ expression in a large, well-characterized cohort group $(23,30-32)$ with respect to endometrioid adenocarcinoma histology. Additionally, several endometrial epithelial cell lines were analyzed for the expression of this subunit by using immunohistochemical and molecular biology techniques.

\section{Material and methods}

Tissue samples. Pathological and surgical records of 231 patients who had been operated in the First Department of Obstetrics and Gynecology, Ludwig-Maximilians-University Munich between 1990 and 2002 were reviewed for this retrospective analysis. The evaluated patient group has been previously well-characterized $(23,30-32)$, with 221 analyzed cases of endometrioid adenocarcinomas (23). In this study 10 additional cases have been included and the inhibin- $\alpha$ subunit expression was evaluated in regard to endometrioid histology. In this re-evaluation, women with histological types other than endometrioid adenocarcinomas (mucinous, serous, clear-cell or mixed adenocarcinomas and squamous-cell, transitional-cell, small-cell or undifferentiated carcinomas) were excluded from this study as previously described $(30,33)$. Additionally, patients with variants of endometrioid adenocarcinoma (including the variant with squamous differentiation, villoglandular variant, secretory variant and ciliated cell variant) were also excluded from this study.

Patient data were obtained from the hospital tumor registry, an automated database and a chart review as previously described $(23,32)$. All cases of recurrence had radiographic evidence of disease or biopsy-proven progression of disease. The records of patients who died of disease were considered to be uncensored; the records of all patients who were alive at follow-up or who did not die of disease (or a related cause) were considered to be censored. Additionally, the cases for which the exact cause of death was unknown but died within two years after the diagnosis of a metastatic lesion were also considered as censored cases $(23,32)$.

Immunohistochemistry. Immunohistochemistry was performed using a combination of pressure cooker heating and the standard streptavidin-biotin-peroxidase complex by using the mouse-IgG-Vectastain Elite ABC kit (Vector
Laboratories, Burlingame, CA, USA) as previously described $(23,24)$. The mouse monoclonal antibody used for the experiments was the inhibin- $\alpha$, clone R1, monoclonal mouse IgG2a, diluted in PBS 1:50 as previously described (23-25).

Cells and cell culture. The endometrial cancer cell lines Ishikawa plus (estrogen receptor positive), Ishikawa minus (estrogen receptor negative), HEC-1A, HEC-1B, and RL95-2 were obtained from ATCC (LGC Promochem GmbH, Wesel, Germany) and were grown in Quantum 263 medium (PAA, Pasching, Austria), supplemented with antibiotics at $37^{\circ} \mathrm{C}$ in a humidified atmosphere with $5 \% \mathrm{CO}_{2}$ as previously described $(34,35)$.

Immunofluorescence analysis. Cells grown on glass coverslips were fixed with acetone for $10 \mathrm{~min}$ at room temperature and washed twice with PBS. Non-specific binding was blocked by incubating the sections with Ultra-V-Block (Lab Vision, Fremont, CA, USA) for $15 \mathrm{~min}$ at room temperature. Thereafter, slides were incubated with inhibin- $\alpha$ antibody (1:50 in dilution medium provided by DAKO, Glostrup, Denmark) overnight at $4{ }^{\circ} \mathrm{C}$, followed by incubation with a 1:500 diluted Cy3-conjugated goat anti-mouse antibody (Dianova, Hamburg, Germany). The slides were finally embedded in mounting buffer containing 4,6-diamino-2phenylindole (DAPI) resulting in blue staining of the nuclei. Slides were embedded with Vectashield mounting medium (Axxora, Lörrach, Germany) and examined with a Zeiss (Jena, Germany) Axiophot photomicroscope. Digital images were obtained with a digital camera system (AxioCam, Zeiss) and saved on a computer with the microscope software AxioVision (version 4.7, Zeiss).

RT-PCR analysis. RNA was extracted from cells by using the Nucleospin RNA II kit (Macherey-Nagel, Düren, Germany) as previously described $(35,35 \mathrm{a})$. Reverse transcription was performed with M-MLV reverse transcriptase and oligo-dT (Promega, Mannheim, Germany) as recommended by the supplier. PCR was performed in an Eppendorf Mastercycler with GoTaq (Promega). Primer sequences were (5'-3'): CCGGCCATCCCAGCATACACGC (forward primer) and GAGTTGAGCGTCGGGCTCTC (backward primer) and amplified a 359 bp product of the inhibin- $\alpha$ cDNA. PCR cycling was performed after a 5 min initiation at $94^{\circ} \mathrm{C}$ with 36 cycles of $1 \mathrm{~min}$ at $94^{\circ} \mathrm{C}, 1 \mathrm{~min}$ at $57^{\circ} \mathrm{C}, 2 \mathrm{~min}$ at $72^{\circ} \mathrm{C}$, followed by a 5 min extension at $72^{\circ} \mathrm{C}$. For a cDNA quality control, actin primers [forward primer (5'-3'): CGAGAAG CTGTGCTACGTCG; backward primer (5'-3'): CGCT CAGGAGGAGCAATGAT], amplifying a 366 bp product, were used as previously described (35a). As a further control, cDNA was omitted (water control) to reveal any PCR contaminations. PCR products were separated on a $1.5 \%$ agarose gel, including a pBR328 marker (Roth, Karlsruhe, Germany). Gels were stained with Sybr-Safe (1:10,000 dilution) (Invitrogen, Karlsruhe, Germany) prior to gel electrophoresis and after a completed run tranferred on a UVpermeable tray to a Bio-Rad Image Analyzer (Bio-Rad, Munich, Germany). The generated electronic picture file was exported as a TIFF file and imported in a PowerPoint presentation file in order to crop and label the figure. 
Statistical analysis. The intensity and distribution patterns of the specific inhibin- $\alpha$-subunit immunohistochemical cytoplasmic staining reaction were evaluated using a semiquantitative score as previously described, used to assess the expression pattern of inhibin/activin subunits $(23,24,35 \mathrm{a}, 36)$. The IRS score was calculated by multiplication of the optical staining intensity (graded as 0 , no staining; 1, weak; 2, moderate; and 3, strong staining) and the percentage of the positive stained cells $(0$, no staining; $1,<10 \% ; 2,11-50 \% ; 3$, $51-80 \%$; and $4,>81 \%$ of the cells).

For the purposes of the statistical survival analysis, the median of the inhibin- $\alpha$ staining intensity for all tumor samples was used (median for inhibin- $\alpha=0$ ) as previously described (23). Therefore, the IRS value $\geq 1$ was considered to be a negative expression. For comparison of the increased/ positive vs. not increased/negative immunostaining in tumor samples the $\chi^{2}$ test and the exact Fisher's test were used where applicable.

The outcomes analyzed were progression-free survival, cause-specific survival and overall survival. Univariate analysis was performed with Kaplan-Meier life-table curves to estimate survival and were compared using the log-rank test (37). Prognostic models used multivariate Cox regression analysis for multivariate analyses of survival. Data were adjusted for age ( $\leq 65$ years vs. $>65$ years), FIGO stage (FIGO I/II vs. FIGO III/IV), WHO grade (grade 1+2 vs. grade 3 ), lymph node involvement (categorical variable), lymphovascular space invasion (positive vs. negative), myometrial invasion (positive vs. negative), cervical invasion (positive vs. negative), ovarian invasion (positive vs. negative) and inhibin- $\alpha$ (positive vs. negative). The variables were entered in a forward stepwise manner (38). Significance of differences was assumed at $\mathrm{p} \leq 0.05$ (SPSS version 16.0; SPSS Inc., Chicago, IL).

\section{Results}

Clinicopathological characterization. The clinicopathological features of the endometrial carcinomas are summarized in Table I. The median patient's age at the time of diagnosis was 65.56 years (range, 36.18-89.35 years). The pathological stage and histological subtype were determined for each surgical specimen according to the 1988 International Federation of Gynecology and Obstetrics (FIGO) criteria (39). One-hundred and eighty-three $(79.2 \%)$ patients were diagnosed in FIGO stage I, while 16 (6.9\%) and 24 (10.4\%) patients had FIGO stages II and III, respectively, and 8 patients (3.5\%) presented with metastatic disease (FIGO IV).

The histological classification was performed according to the World Health Organization system. There were 142 $(61.5 \%)$ of well-differentiated (G1) tumors, $63(27.3 \%)$ moderately-differentiated (G2) and 26 (11.3\%) poorlydifferentiated (G3) tumor samples. Of the 231 analyzed endometrial tumor samples, 75 patients $(32.5 \%)$ presented with a myometrial invasion $>50 \%$ of the uterine size. Additionally, $26(11.3 \%)$ and 16 patients $(6.9 \%)$, presented with a cervical and ovarian metastatic invasion, respectively. Lymphovascular space invasion was demonstrated in 19 $(8.2 \%)$ patients.

Pelvic and/or para-aortic lymph node sampling was performed for 162 patients $(70.1 \%)$ while 13 patients $(5.6 \%)$
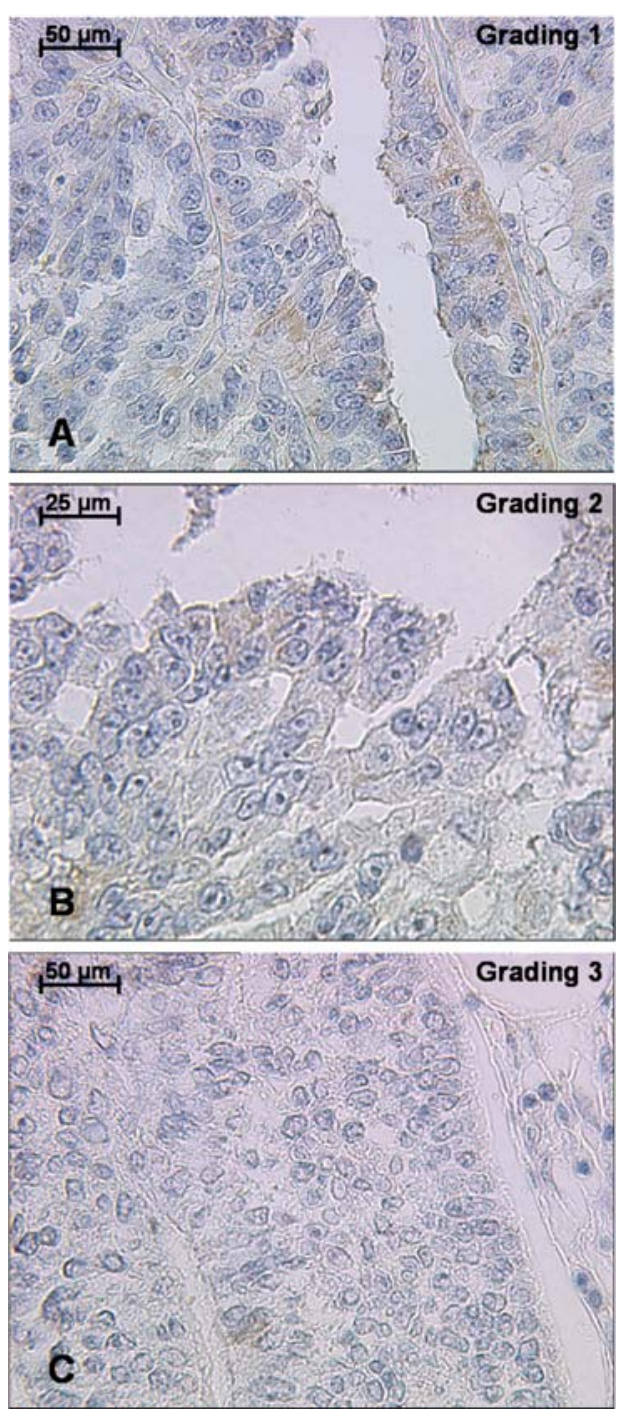

Figure 1. (A) and (B). Expression of inhibin- $\alpha$ subunits in human endometrial adenocarcinomas. Immunohistochemical analysis for inhibin- $\alpha$ demonstrated a weak characteristic cytoplasmatic staining reaction in endometrioid cancer tissue of histopathological differentiation grade 1 (A) (lens x20) and grade 2 (B) (lens x40), while grade 3 tissue samples mostly did not demonstrated a reaction against the used antibody (C) (lens x20).

demonstrated lymph node metastasis. A low FIGO stage (FIGO Ia), obesity, advanced age and excessive comorbidity were factors against a full surgical staging in 69 patients $(29.9 \%)$. Obesity was observed in $84(36.5 \%)$ cases, while 94 $(40.7 \%)$ and $28(12.1 \%)$ patients presented with hypertension and diabetes respectively. Of the 231 analyzed patients, 82 $(35.5 \%)$ received radiation therapy, while $7(3 \%)$ and 5 patients $(2.2 \%)$, respectively, received anti-hormonal therapy and chemotherapy. During the follow-up interval, tumor recurrence was observed in 32 patients $(13.9 \%)$ and 25 patients $(10.8 \%)$ died of disease. Sixty-two patients $(26.8 \%)$ died during the entire observation period.

Endometrial carcinoma samples. The mean of the IRS score for inhibin- $\alpha$ was $0.45 \pm 0.972$ (mean \pm SD) and the staining intensity $0.24 \pm 0.429$ (mean \pm SD). Positive inhibin- $\alpha$ immunostaining was observed in $56(24.2 \%)$ endometrial carcinoma samples (Fig. 1). Analysis of positive and negative expression, 
Table I. Clinicopathological characteristics and univariate statistical analysis for the inhibin- $\alpha$ subunit according to various clinicopathological features.

\begin{tabular}{|c|c|c|c|c|}
\hline & \multicolumn{3}{|c|}{ Inhibin- $\alpha, \mathrm{n}(\%)$} & \multirow[b]{2}{*}{$\chi^{2}$} \\
\hline & Total $(n=231)$ & Negative & Positive & \\
\hline \multicolumn{5}{|l|}{ General characteristics } \\
\hline \multicolumn{5}{|l|}{ Age (years) } \\
\hline$\leq 65$ & $118(51.1)$ & $83(70.3)$ & $35(29.7)$ & \multirow[t]{2}{*}{ NS } \\
\hline$>65$ & $113(48.9)$ & $92(81.4)$ & $21(18.6)$ & \\
\hline \multicolumn{5}{|l|}{ Adiposites } \\
\hline Negative & $147(63.5)$ & $108(73.3)$ & $39(26.7)$ & \multirow[t]{2}{*}{ NS } \\
\hline Positive & $84(36.5)$ & $67(79.8)$ & $17(20.2)$ & \\
\hline \multicolumn{5}{|l|}{ Diabetes } \\
\hline Negative & $203(87.9)$ & $150(73.9)$ & $53(26.1)$ & \multirow[t]{2}{*}{ NS } \\
\hline Positive & $28(12.1)$ & $25(89.3)$ & $3(10.7)$ & \\
\hline \multicolumn{5}{|l|}{ Hypertension } \\
\hline Negative & $137(59.3)$ & $97(70.8)$ & $40(29.2)$ & \multirow[t]{2}{*}{0.042} \\
\hline Positive & $94(40.7)$ & $78(83.0)$ & $16(17.0)$ & \\
\hline \multicolumn{5}{|l|}{ Surgical characteristics } \\
\hline \multicolumn{5}{|l|}{ FIGO stage } \\
\hline FIGO I & $183(79.2)$ & $133(72.7)$ & $50(27.3)$ & \multirow[t]{12}{*}{0.027} \\
\hline FIGO Ia & $30(13.0)$ & $18(60.0)$ & $12(40.0)$ & \\
\hline FIGO Ib & $108(46.8)$ & $79(73.1)$ & $29(26.9)$ & \\
\hline FIGO Ic & $45(19.5)$ & $36(80.0)$ & $9(20.0)$ & \\
\hline FIGO II & $16 \quad(6.9)$ & $11(68.8)$ & $5(31.3)$ & \\
\hline FIGO 2a & $3 \quad(1.3)$ & $2(66.7)$ & $1(33.3)$ & \\
\hline FIGO $2 b$ & $13 \quad(5.6)$ & $9(69.2)$ & $4(30.8)$ & \\
\hline FIGO III & $24(10.4)$ & $23(95.8)$ & $1 \quad(4.2)$ & \\
\hline FIGO 3a & $9 \quad(3.9)$ & $8(88.9)$ & $1(11.1)$ & \\
\hline FIGO 3b & $4 \quad(1.7)$ & $4(100)$ & $0 \quad(0)$ & \\
\hline FIGO $3 c$ & $11 \quad(4.8)$ & $11(100)$ & $0 \quad(0)$ & \\
\hline FIGO IV & $8 \quad(3.5)$ & $8(100)$ & $0 \quad(0)$ & \\
\hline \multicolumn{5}{|l|}{ Lymphonodectomy } \\
\hline Not performed & $69(29.9)$ & $53(76.8)$ & $16(23.2)$ & \multirow[t]{2}{*}{ NS } \\
\hline Performed & $162(70.1)$ & $122(75.3)$ & $40(24.7)$ & \\
\hline \multicolumn{5}{|l|}{ Pathological characteristics } \\
\hline \multicolumn{5}{|l|}{ Grading } \\
\hline Grade 1 & $142(61.5)$ & $100(70.4)$ & $42(29.6)$ & \multirow[t]{3}{*}{0.030} \\
\hline Grade 2 & $63(27.3)$ & $51(81.0)$ & $12(19.0)$ & \\
\hline Grade 3 & $26(11.3)$ & $24(92.3)$ & $2(7.7)$ & \\
\hline \multicolumn{5}{|l|}{ Myometrial invasion } \\
\hline Endometrial invasion & $32(13.9)$ & $20(62.5)$ & $12(37.5)$ & \multirow[t]{3}{*}{0.014} \\
\hline$\leq 50 \%$ myometrium & $124(53.7)$ & $90(72.6)$ & $34(27.4)$ & \\
\hline$>50 \%$ myometrium & $75(32.5)$ & $65(86.7)$ & $10(13.3)$ & \\
\hline \multicolumn{5}{|l|}{ Cervical invasion } \\
\hline Negative & 205 (88.7) & $154(75.1)$ & $51(24.9)$ & \multirow[t]{2}{*}{ NS } \\
\hline Positive & $26(11.3)$ & $21(80.8)$ & $5(19.2)$ & \\
\hline Ovarial invasion & & & & \\
\hline Negative & $215(93.1)$ & $160(74.4)$ & $55(25.6)$ & NS \\
\hline Positive & $16 \quad(6.9)$ & $15(93.8)$ & $1 \quad(6.3)$ & \\
\hline
\end{tabular}


Table I. Continued.

\begin{tabular}{|c|c|c|c|c|}
\hline & \multicolumn{3}{|c|}{ Inhibin- $\alpha, \mathrm{n}(\%)$} & \multirow[b]{2}{*}{$\chi^{2}$} \\
\hline & Total $(n=231)$ & Negative & Positive & \\
\hline \multicolumn{5}{|l|}{ LN status } \\
\hline Negative & $149(64.5)$ & $109(73.2)$ & $40(26.8)$ & \multirow[t]{3}{*}{ NS } \\
\hline Positive & $13(5.6)$ & $13(100)$ & $0 \quad(0)$ & \\
\hline Unknown & $69(29.9)$ & $53(76.8)$ & $16(23.2)$ & \\
\hline \multicolumn{5}{|l|}{ LVSI } \\
\hline Negative & $212(91.8)$ & $159(75.0)$ & $53 \quad(25)$ & \multirow[t]{2}{*}{ NS } \\
\hline Positive & $19(8.2)$ & $16(84.2)$ & $3(15.8)$ & \\
\hline \multicolumn{5}{|c|}{ Therapeutic characteristics } \\
\hline \multicolumn{5}{|l|}{ Radiotherapy } \\
\hline Negative & $143(61.9)$ & $106(74.1)$ & 37 (25.9) & \multirow[t]{3}{*}{$\mathrm{NS}$} \\
\hline Positive & $82(35.5)$ & $63(76.8)$ & $19(23.2)$ & \\
\hline Denial & $6 \quad(2.6)$ & $6(100)$ & $0 \quad(0)$ & \\
\hline \multicolumn{5}{|c|}{ Anti-hormonal therapy } \\
\hline Negative & $224(97.0)$ & $171(76.3)$ & $53(23.7)$ & \multirow[t]{2}{*}{ NS } \\
\hline Positive & $7 \quad(3.0)$ & $4(57.1)$ & $3(42.9)$ & \\
\hline \multicolumn{5}{|l|}{ Chemotherapy } \\
\hline Negative & $225(97.4)$ & $169(75.1)$ & $56(24.9)$ & \multirow[t]{3}{*}{ NS } \\
\hline Positive & $5 \quad(2.2)$ & $5(100)$ & $0 \quad(0)$ & \\
\hline Denial & $1 \quad(0.4)$ & $1(100)$ & $0 \quad(0)$ & \\
\hline
\end{tabular}

NS, not significant.

using univariate analysis ( $\chi^{2}$ test) revealed a significant association of inhibin- $\alpha$ immunolabeling with histological grading, FIGO stages and myometrial invasion (Table I). Interestingly, in poorly-differentiated endometrioid adenocarcinomas the expression of inhibin- $\alpha$ was down-regulated, confirming previous results $(23,25,40)$.

Inhibin- $\alpha$ in human endometrial epithelial carcinoma cell lines. The Ishikawa cell line is derived from a well-differentiated endometrial adenocarcinoma with high adhesiveness and glandular and luminal epithelial characteristics (41-43). The HEC endometrial cancer cells are also derived from a well-differentiated endometrial adenocarcinoma but with high polarization and poor adhesiveness (44-47). In contrast, RL95-2 cells have been isolated from poorly-differentiated endometrial adenosquamous carcinomas (48).

Several undifferentiated cell strains have been developed from these original cell lines with different characteristics, especially regarding estrogen and progesterone receptor expression (i.e. HEC-1A and HEC-1B; Ishikawa plus and Ishikawa minus) $(41,44)$. While Ishikawa positive cells express estrogen and progesterone receptors (49-51), their clone Ishikawa minus lacks both receptors $(42,52)$. HEC-1A cells synthesize both steroid receptors $(49,53)$, though the HEC-1B cells do not express the progesterone receptor $(49,53,54)$. Similarly, the RL95-2 cell line expresses the estrogen receptor without any detectable levels of the progesterone receptor $(49,55)$.
We, therefore, tested the expression of inhibin- $\alpha$ in the human cancer cell lines Ishikawa plus (estrogen receptor positive), Ishikawa minus (estrogen receptor negative), HEC-1A, HEC-1B and RL95-2. Immunofluorescence analysis of all cell lines demonstrated immunolabeling of this novel $\alpha$-subunit at the protein level. Expression of inhibin- $\alpha$ was primarily found to be located in the cytoplasma of the analyzed endometrial cancer cell lines (Fig. 2).

To analyze the inhibin- $\alpha$ subunit expression at the transcriptional level, RNA was extracted from samples of human endometrial cancer cells, transcribed into cDNA, and analyzed by RT-PCR analysis using specific inhibin- $\alpha$ primers. Fig. 3 demonstrates that the mRNA of the inhibin- $\alpha$ subunit is expressed in all the analyzed endometrial cancer cell lines. Interestingly, Ishikawa plus demonstrated a lower inhibin- $\alpha$ mRNA compared to the other cancer cell lines.

Survival analysis. The overall median follow-up was 85.53 months (range 0.03-179.77 months). Univariate survival analysis demonstrated significant differences in progressionfree survival, cause-specific survival and overall survival for inhibin- $\alpha$. Overall, a positive inhibin- $\alpha$ staining intensity resulted in worse progression-free and overall survival, although without statistical significance (Fig. 4).

The Cox regression led to a model containing three independent terms that were predictive of progression-free survival: FIGO stage $(\mathrm{p}=0.003)$, cervical invasion $(\mathrm{p}=0.003)$, LVSI $(\mathrm{p}=0.018)$ and inhibin- $\alpha(\mathrm{p}=0.031)$. Independent 

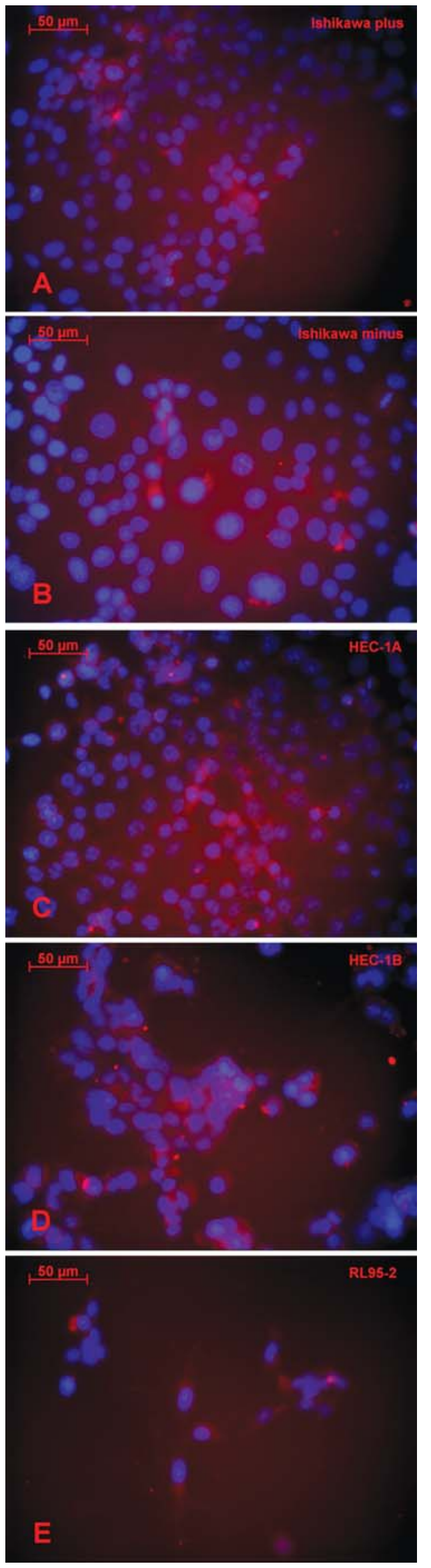

Figure 2. Expression of inhibin- $\alpha$ demonstrated by immunofluorescence in endometrial cancer cells. The inhibin- $\alpha$ subunit was detected in Ishikawa plus (A), Ishikawa minus (B), HEC-1A (C), HEC-1B (D) and RL95-2 (E) cell lines with a cytoplasmatic staining reaction. Lens $\mathrm{x} 40$.

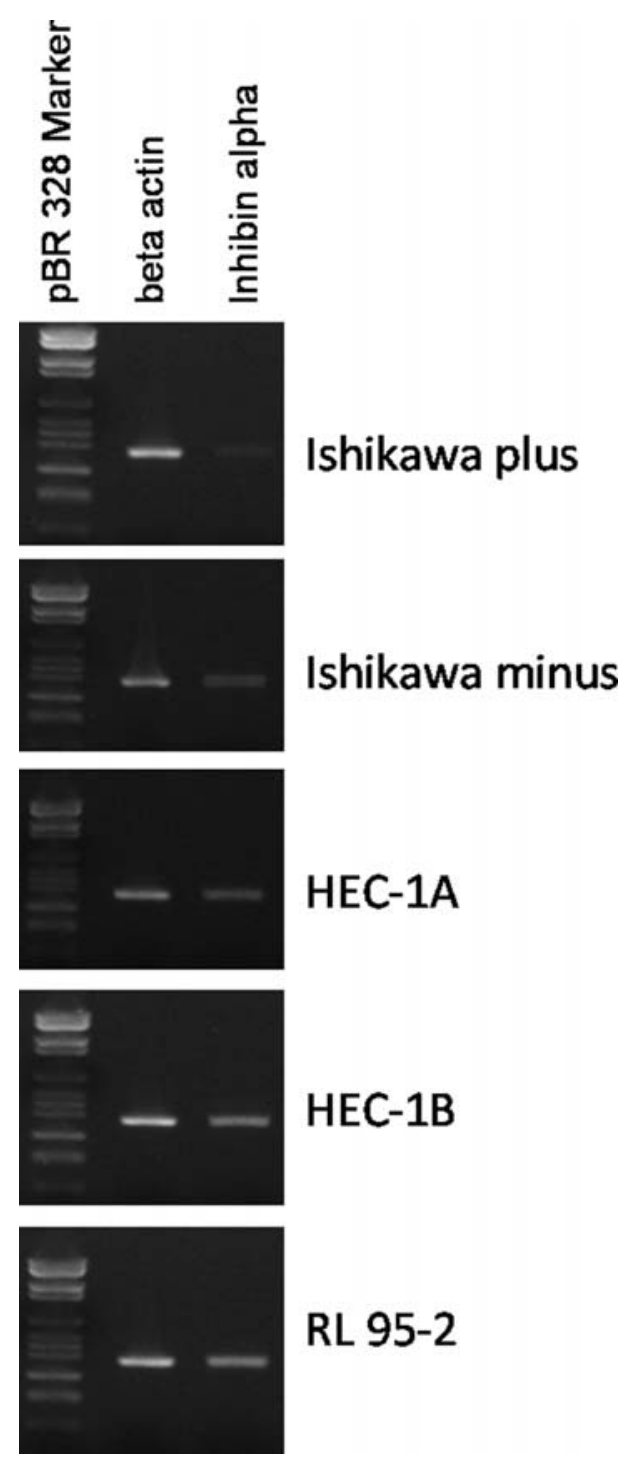

Figure 3. Inhibin- $\alpha$ subunit mRNA detection in endometrial cancer cell lines. The mRNA of the inhibin- $\alpha$ subunit was detected in Ishikawa plus (A), Ishikawa minus (B), HEC-1A (C), HEC-1B (D) and RL95-2 (E) using RT-PCR.

prognostic factors for cause-specific survival were the FIGO stage $(p=0.009)$ and cervical involvement $(p=0.001)$. The overall survival was influenced by the patient's age $(\mathrm{p}<0.001)$, histological grading $(\mathrm{p}=0.046)$, cervical involvement $(\mathrm{p}<0.001)$, positive lymph node status $(\mathrm{p}=0.009)$ and inhibin- $\alpha$ expression $(\mathrm{p}=0.003)$ (Table II).

\section{Discussion}

Although initially characterized as endocrine and paracrine hormonal regulators of the hypothalamic-pituitary-gonadal axis (18), it is now evident that inhibins and activins are expressed in a wide range of tissues including normal human endometrium (24), cultured human endometrial cells $(22,56,57)$, hyperplastic and malignant human endometrial tissue $(26,58,59)$. Recently, the differential immunohistochemical expression of the inhibin- $\alpha,-\beta A$ and $-\beta B$ subunits was demonstrated in a cohort group of 302 endometrial cancer patients (23). Although inhibin- $\alpha$ immunoreactivity 
Table II. Hazard ratios by multivariate Cox regression analysis.

\begin{tabular}{|c|c|c|c|c|c|c|}
\hline & \multicolumn{2}{|c|}{ Progression-free survival } & \multicolumn{2}{|c|}{ Cause-specific survival } & \multicolumn{2}{|c|}{ Overall survival } \\
\hline & RR $(5-95 \% \mathrm{CI})$ & p-value & $\mathrm{RR}(5-95 \% \mathrm{CI})$ & p-value & RR $(5-95 \% \mathrm{CI})$ & p-value \\
\hline $\begin{array}{l}\text { Age } \\
(\leq 65 \text { vs. }>65 \text { years })\end{array}$ & & & & & $3.793(2.008-7.162)$ & $<0.001$ \\
\hline $\begin{array}{l}\text { FIGO } \\
\text { (I/II vs. III/IV) }\end{array}$ & $3.412 \quad(1.508-7.72)$ & 0.003 & $3.187(1.336-7.603)$ & 0.009 & & \\
\hline $\begin{array}{l}\text { Grading } \\
(1 / 2 \text { vs. } 3)\end{array}$ & & & & & $1.92 \quad(1.013-3.638)$ & 0.046 \\
\hline $\begin{array}{l}\text { Cervical invasion } \\
\text { (positive vs. negative) }\end{array}$ & $3.545(1.548-8.119)$ & 0.003 & $4.31(1.768-10.506)$ & 0.001 & $4.042(2.133-7.658)$ & $<0.001$ \\
\hline $\begin{array}{l}\text { Lymph node status } \\
\text { (negative vs. positive) }\end{array}$ & & & & & $1.444(1.094-1.907)$ & 0.009 \\
\hline $\begin{array}{l}\text { LVSI } \\
\text { (positive vs. negative) }\end{array}$ & $3.143(1.218-8.107)$ & 0.018 & & & $2.075(1.039-4.143)$ & 0.039 \\
\hline $\begin{array}{l}\text { Inhibin- } \alpha \\
\text { (negative vs. positive) }\end{array}$ & $0.109(0.015-0.817)$ & 0.031 & & & $0.294(0.131-0.657)$ & 0.003 \\
\hline
\end{tabular}
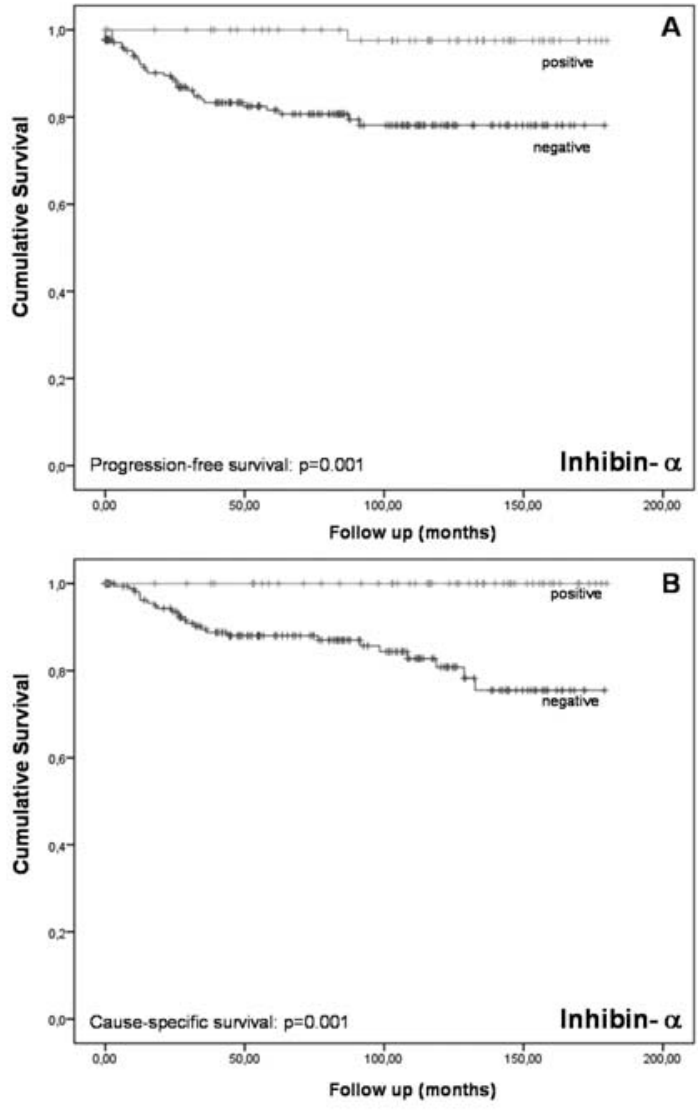

was a significant independent prognostic factor, the $B \mathrm{~A}-$ and $\beta B$ expression did not affect patient survival (23). In this reevaluation of 231 endometrioid uterine adenocarcinomas, an association between the surgical stage, histological

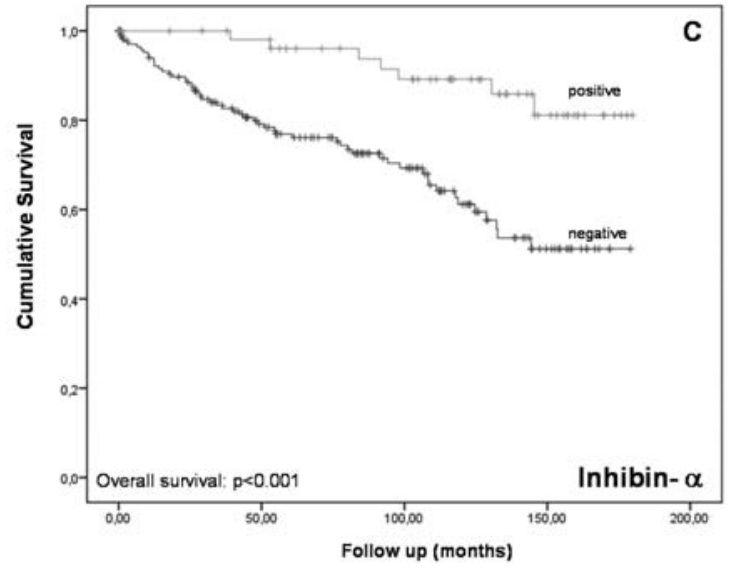

Figure 4. Kaplan-Meier curves of clinical outcome regarding inhibin- $\alpha$ expression for progression-free survival (A), cause-specific survival (B) and overall survival (C). The survival of endometrial cancer patients was significantly associated with the staining intensity of the inhibin- $\alpha$ subunit.

differentiation and myometrial invasion and inhibin- $\alpha$ immunolabeling was demonstrated, suggesting a substantial function of this subunit in human endometrial carcinogenesis. Moreover, all analyzed endometrial cell cancer lines demonstrated a positive expression of this subunit by immunohistochemical and molecular biological techniques.

The most extensive knowledge of the inhibin-subunits is mainly a result of experiments in knock-out mice. It appears that the most important function of the $\alpha$-subunit is its tumor suppressor activity, which was first identified after functional deletion of the inhibin- $\alpha$ gene in mice $(16,17)$. Since immunolabeling of inhibin- $\alpha$ constitutes an independent prognostic 
factor for progression-free and overall survival in endometrioid adenocarcinomas, a putative tumor suppressive function in human endometrial cancer might be suggested $(16,17)$.

Although immunolabeling of the inhibin- $\alpha$ subunit may be useful in identifying high risk patients, the action of this subunit and its dimeric glycoproteins inhibin A and B in endometrial carcinogenesis is still not elucidated. One major reason for this might be the fact that specific signaling receptors for inhibins have not yet been identified (60). Meanwhile it is known that inhibins are capable of binding type II activin receptors and BMP receptors through their $\beta$-subunits, although with a very low affinity (60). This led to the assumption that additional inhibin-binding proteins might increase the affinity of inhibin for the type II receptors. Although several putative inhibin binding proteins have been described (61), only the type III TGF- $\beta$ receptor (TGFBR3), also known as betaglycan, has been demonstrated to increase the binding affinities of inhibins to the activin and BMP type II receptors $(7,62)$. The loss of betaglycan expression seems to be a key feature in carcinogenesis, associated with increased cancer cell motility and invasiveness (63-67) as well as with increased histological tumor grade and clinical stage $(40,68)$. Interestingly, in ovarian cancer cells, loss of inhibin A responsiveness has been associated with a more aggressive tumor phenotype (69). Moreover, overexpression of betaglycan resulted in a significant reduction in cell migration whereas inhibin- $\alpha$ gene silencing enhanced both migration and invasion (63). Whether the inhibin/betaglycan mediated cellular processes might also be disrupted in endometrial cancer is still undefined.

In order to elucidate the function of inhibin in human cancer, the understanding of the cell type-specific action of inhibin seems to be an important step. Therefore, adequate in vitro models are necessary to address these important questions. The most widely used models for assessing endometrial carcinogenesis are the endometrial cancer cell lines. The first available endometrial cancer cell line was the HEC-1 cell line, which was derived almost 40 years ago (44). The most commonly used endometrial epithelial cell lines are derived from poorly-differentiated (i.e. RL95-2) or welldifferentiated (i.e. Ishikawa) endometrial adenocarcinomas $(41,48)$. Moreover, several undifferentiated cell strains were developed from these original cell lines with different characteristics, especially regarding their expression of the estrogen and progesterone receptors (i.e. HEC-1A and HEC-1B; Ishikawa plus and Ishikawa minus) $(41,44)$. Several inhibin-subunits have been observed in the Ishikawa and RL95-2 cell lines by using immunohistochemical techniques $(35,70,71)$. In this study, inhibin- $\alpha$ synthesis was demonstrated in several endometrial cancer cell lines by using immunohistochemical and molecular biological techniques. The use of these endometrial cancer cell lines, including subclones with minimal or no steroid receptor expression, seems to be of primary importance, since an association between activin and estrogen in regulating breast cancer cells has been suggested (72). Therefore, depending on the primary aim, HEC, Ishikawa and RL95-2 cell lines could be used in assessing the inhibin- $\alpha$ function in endometrial carcinogenesis.

Overall, the inhibin- $\alpha$ subunit demonstrated a significant association with histological grading, surgical staging and myometrial invasion in patients with endometrioid adenocarcinomas. Additionally, survival analysis demonstrated that inhibin- $\alpha$ immunoreactivity significantly affected progressionfree, cause-specific and overall survival of patients with endometrioid adenocarcinomas, confirming previous results. Moreover, several endometrial epithelial cancer cell lines can synthesize the inhibin- $\alpha$ subunit, constituting adequate in vitro models for assessing inhibin- $\alpha$ function in endometrial carcinogenesis.

\section{Acknowledgements}

The author would like to thank Dr S. Worbs, Dr N. Shabani, Mrs. C. Kuhn, Mrs. S. Kunze, Mrs. S. Schulze, Dr D. Dian, Dr A. Gingelmaier, Dr C. Schindlbeck, Dr A. Brüning, Dr U. Jeschke, Professor H. Sommer and Professor K. Friese for their help in conducting the primary study. Additionally we would like to thank Professor D. Hölzel - Institute of Medical Informatics, Biometry and Epidemiology, LudwigMaximilians-University Munich and Mr. M. Schmidt of the Munich Tumor Registry for supplying the survival data. This study was partially supported by the FöFoLe program of the Ludwig-Maximilians-University Munich (297/03), the Friedrich-Baur-Institute Munich and the Weigland Stipendium Program of the Ludwig-Maximilians-University Munich for I.M. I.M. is supported by the German Research Foundation (Deutsche Forschungsgemeinschaft, DFG BR 3641/3-1).

\section{References}

1. Amant F, Moerman P, Neven P, Timmerman D, Van Limbergen E and Vergote I: Endometrial cancer. Lancet 366: 491-505, 2005.

2. Prat J: Prognostic parameters of endometrial carcinoma. Hum Pathol 35: 649-662, 2004.

3. Jereczek-Fossa B, Badzio A and Jassem J: Surgery followed by radiotherapy in endometrial cancer: analysis of survival and patterns of failure. Int J Gynecol Cancer 9: 285-294, 1999.

4. Deligdisch L and Holinka CF: Endometrial carcinoma: two diseases? Cancer Detect Prev 10: 237-246, 1987.

5. Bokhman JV: Two pathogenetic types of endometrial carcinoma. Gynecol Oncol 15: 10-17, 1983 .

6. Lax SF: Molecular genetic pathways in various types of endometrial carcinoma: from a phenotypical to a molecularbased classification. Virchows Arch 444: 213-223, 2004.

7. Gloeckler Ries LA, Reichman ME, Lewis DR, Hankey BF and Edwards BK: Cancer survival and incidence from the Surveillance, Epidemiology, and End Results (SEER) program. Oncologist 8: 541-552, 2003.

8. Vale W, Wiater E, Gray P, Harrison C, Bilezikjian L and Choe S: Activins and inhibins and their signaling. Ann N Y Acad Sci 1038: 142-147, 2004.

9. Vale W, Rivier C, Hsueh A, et al: Chemical and biological characterization of the inhibin family of protein hormones. Recent Prog Horm Res 44: 1-34, 1988.

10. Xia Y and Schneyer AL: The biology of activin: recent advances in structure, regulation and function. J Endocrinol 202: 1-12, 2009.

11. Jones RL, Stoikos C, Findlay JK and Salamonsen LA: TGF-beta superfamily expression and actions in the endometrium and placenta. Reproduction 132: 217-232, 2006.

12. Stoikos CJ, Harrison CA, Salamonsen LA and Dimitriadis E: A distinct cohort of the TGFbeta superfamily members expressed in human endometrium regulate decidualization. Hum Reprod 23: 1447-1456, 2008 .

13. Delvenne CG, Winkler-Gol RA, Piccart MJ, et al: Expression of c-erbB2, TGF-beta 1 and pS2 genes in primary human breast cancers. Eur J Cancer 28: 700-705, 1992.

14. Danielpour D: Functions and regulation of transforming growth factor-beta (TGF-beta) in the prostate. Eur J Cancer 41: 846-857, 2005. 
15. Risbridger GP, Ball EM, Wang H, Mellor SL and Peehl DM: Re-evaluation of inhibin alpha subunit as a tumour suppressor in prostate cancer. Mol Cell Endocrinol 225: 73-76, 2004.

16. Matzuk MM, Finegold MJ, Su JG, Hsueh AJ and Bradley A: Alpha-inhibin is a tumour-suppressor gene with gonadal specificity in mice. Nature 360: 313-319, 1992.

17. Matzuk MM, Finegold MJ, Mather JP, Krummen L, Lu H and Bradley A: Development of cancer cachexia-like syndrome and adrenal tumors in inhibin-deficient mice. Proc Natl Acad Sci USA 91: 8817-8821, 1994

18. Welt CK: The physiology and pathophysiology of inhibin, activin and follistatin in female reproduction. Curr Opin Obstet Gynecol 14: 317-323, 2002

19. Risbridger GP, Schmitt JF and Robertson DM: Activins and inhibins in endocrine and other tumors. Endocr Rev 22: 836-858, 2001.

20. Mabuchi Y, Yamoto M, Minami S and Umesaki N: Immunohistochemical localization of inhibin and activin subunits, activin receptors and Smads in ovarian endometriosis. Int J Mol Med 25: 17-23, 2010

21. Zheng W, Luo MP, Welt C, et al: Imbalanced expression of inhibin and activin subunits in primary epithelial ovarian cancer. Gynecol Oncol 69: 23-31, 1998.

22. Petraglia F, Florio P, Luisi S, et al: Expression and secretion of inhibin and activin in normal and neoplastic uterine tissues. High levels of serum activin A in women with endometrial and cervical carcinoma. J Clin Endocrinol Metab 83: 1194-1200, 1998.

23. Mylonas I, Worbs S, Shabani N, et al: Inhibin-alpha subunit is an independent prognostic parameter in human endometrial carcinomas: analysis of inhibin/activin-alpha, -betaA and -betaB subunits in 302 cases. Eur J Cancer 45: 1304-1314, 2009

24. Mylonas I, Jeschke U, Wiest I, et al: Inhibin/activin subunits alpha, beta-A and beta-B are differentially expressed in normal human endometrium throughout the menstrual cycle. Histochem Cell Biol 122: 461-471, 2004

25. Worbs S, Shabani N, Mayr D, et al: Expression of the inhibin/ activin subunits $(-\alpha,-\beta \mathrm{A}$ and $-\beta \mathrm{B})$ in normal and carcinogenic endometrial tissue: Possible immunohistochemical differentiation markers. Oncol Rep 17: 97-104, 2007

26. Mylonas I, Makovitzky J, Richter DU, Jeschke U, Briese V and Friese K: Expression of the inhibin-alpha subunit in normal, hyperplastic and malignant endometrial tissue: an immunohistochemical analysis. Gynecol Oncol 93: 92-97, 2004.

27. Mylonas I, Jeschke U, Shabani N, Kuhn C, Friese K and Gerber B: Inhibin/activin subunits (inhibin- $\alpha,-\beta A$ and $-\beta B$ ) are differentially expressed in human breast cancer and their metastasis Oncol Rep 13: 81-88, 2005

28. Reis FM, Luisi S, Carneiro MM, et al: Activin, inhibin and the human breast. Mol Cell Endocrinol 225: 77-82, 2004

29. Mylonas I: Inhibin-alpha, -betaA and -betaB subunits in uterine non-endometrioid carcinomas: Prognostic significance and clinical implications. Eur J Cancer 46: 2485-2493, 2010

30. Brüning A, Jückstock JK, Blankenstein T, Makovitzky J, Kunze S and Mylonas I: The metastasis-associated gene MTA3 is downregulated in advanced endometrioid adenocarcinomas Histol Histopathol 25: 1447-1456, 2010.

31. Bassarak N, Blankenstein T, Bruning A, et al: Is lymphadenectomy a prognostic marker in endometrioid adenocarcinoma of the human endometrium? BMC Cancer 10: 224, 2010.

32. Shabani N, Kuhn C, Kunze S, et al: Prognostic significance of oestrogen receptor alpha (ERalpha) and beta (ERbeta) progesterone receptor A (PR-A) and B (PR-B) in endometrial carcinomas. Eur J Cancer 43: 2434-2444, 2007.

33. Mylonas I: Prognostic significance and clinical importance of estrogen receptor $\alpha$ and $\beta$ in human endometrioid adenocarcinomas. Oncol Rep 24: 385-393, 2010.

34. Brüning A, Makovitzky J, Gingelmaier A, Friese K and Mylonas I: The metastasis-associated genes MTA1 and MTA3 are abundantly expressed in human placenta and chorionic carcinoma cells. Histochem Cell Biol 132: 33-38, 2009.

35. Kimmich T, Bruning A, Kaufl SD, et al: Inhibin/activin-betaC and -betaE subunits in the Ishikawa human endometrial adenocarcinoma cell line. Arch Gynecol Obstet 282: 185-191, 2010.

35. a) Mylonas I, Bruning A, Shabani N, Kunze S and Kupka MS Evidence of inhibin/activin subunit betaC and betaE synthesis in normal human endometrial tissue. Reprod Biol Endocrinol 8: 143,2010
36. Mylonas I, Schiessl B, Jeschke U, et al: Expression of inhibin activin subunits alpha (-alpha), beta A (-beta (A)) and beta B (-beta (B)) in placental tissue of normal and intrauterine growth restricted (IUGR) pregnancies. J Mol Histol 37: 43-52, 2006.

37. Kaplan EL and Meier P: Nonparametric estimation from incomplete observations. J Am Stat Assoc 53: 457-481, 1958.

38. Cox DR: Regression models and life tables. J R Stat Soc B 34: $187-220,1972$.

39. Announcements: FIGO stages - 1988 revision. Gynecol Oncol 35: 125-127, 1989.

40. Florio P, Ciarmela P, Reis FM, et al: Inhibin \{alpha\}-subunit and the inhibin coreceptor betaglycan are downregulated in endometrial carcinoma. Eur J Endocrinol 152: 277-284, 2005.

41. Nishida M: The Ishikawa cells from birth to the present. Hum Cell 15: 104-117, 2002.

42. Nishida M, Kasahara K, Kaneko M, Iwasaki H and Hayashi K: [Establishment of a new human endometrial adenocarcinoma cell line, Ishikawa cells, containing estrogen and progesterone receptors]. Nippon Sanka Fujinka Gakkai Zasshi 37: 1103-1111, 1985 (In Japanese)

43. Heneweer C, Schmidt M, Denker HW and Thie M: Molecular mechanisms in uterine epithelium during trophoblast binding: the role of small GTPase RhoA in human uterine Ishikawa cells. J Exp Clin Assist Reprod 2: 4, 2005.

44. Kuramoto H, Tamura S and Notake Y: Establishment of a cell line of human endometrial adenocarcinoma in vitro. Am J Obstet Gynecol 114: 1012-1019, 1972.

45. Martin JC, Jasper MJ, Valbuena D, et al: Increased adhesiveness in cultured endometrial-derived cells is related to the absence of moesin expression. Biol Reprod 63: 1370-1376, 2000.

46. Thie M, Herter $\mathrm{P}$, Pommerenke $\mathrm{H}$, et al: Adhesiveness of the free surface of a human endometrial monolayer for trophoblast as related to actin cytoskeleton. Mol Hum Reprod 3: 275-283, 1997.

47. Ball JM, Moldoveanu Z, Melsen LR, et al: A polarized human endometrial cell line that binds and transports polymeric IgA. In Vitro Cell Dev Biol Anim 31: 196-206, 1995.

48. Christensen C, Deppe G, Saunders D and Malviya V: The use of a human endometrial carcinoma cell line (RL-95) for in vitro testing of chemotherapeutic agents. Gynecol Oncol 28: 25-33, 1987.

49. Di Nezza LA, Jobling T and Salamonsen LA: Progestin suppresses matrix metalloproteinase production in endometrial cancer. Gynecol Oncol 89: 325-333, 2003.

50. Viswanath G, Chatterjee S and Roy P: Assessment of luteinizing hormone receptor function in an endometrial cancer cell line, Ishikawa cells in response to human chorionic gonadotrophin (hCG). Mol Cell Endocrinol 272: 14-21, 2007.

51. Ishikawa A, Kudo M, Nakazawa N, et al: Expression of keratinocyte growth factor and its receptor in human endometrial cancer in cooperation with steroid hormones. Int J Oncol 32: $565-574,2008$

52. Nishida M, Kasahara K, Oki A, Satoh T, Arai Y and Kubo T: Establishment of eighteen clones of Ishikawa cells. Hum Cell 9: 109-116, 1996

53. Horne AW, Lalani EN, Margara RA and White JO: The effects of sex steroid hormones and interleukin-1-beta on MUC1 expression in endometrial epithelial cell lines. Reproduction 131: 733-742, 2006.

54. Gao J and Tseng L: Progesterone receptor (PR) inhibits expression of insulin-like growth factor-binding protein-1 (IGFBP-1) in human endometrial cell line HEC-1B: characterization of the inhibitory effect of PR on the distal promoter region of the IGFBP-1 gene. Mol Endocrinol 11: 973-979, 1997.

55. Wadehra M, Mainigi M, Morales SA, et al: Steroid hormone regulation of EMP2 expression and localization in the endometrium. Reprod Biol Endocrinol 6: 15, 2008.

56. Mylonas I, Jeschke U, Winkler L, et al: Immunohistochemical expression of inhibin-alpha in human endometrium and the in vitro secretion of inhibin, estradiol and cortisol in cultured human endometrial glandular cells. Arch Gynecol Obstet 268: $142-150,2003$

57. Mylonas I, Winkler L, Jeschke U, Briese V and Friese K: Investigations on isolation, purification and cultivation of human endometrial cells and on the in vitro inhibin expression in glandular epithelial cells. Zentralbl Gynakol 125: 415-423, 2003.

58. Otani T, Minami S, Kokawa K, Shikone T, Yamoto M and Nakano R: Immunohistochemical localization of activin A in human endometrial tissues during the menstrual cycle and in early pregnancy. Obstet Gynecol 91: 685-692, 1998 
59. Mylonas I, Makovitzky J, Fernow A, et al: Expression of the inhibin/activin subunits alpha (alpha), beta-A (betaA) and beta$\mathrm{B}$ (betaB) in benign human endometrial polyps and tamoxifenassociated polyps. Arch Gynecol Obstet 272: 59-66, 2005.

60. Bernard DJ, Chapman SC and Woodruff TK: Mechanisms of inhibin signal transduction. Recent Prog Horm Res 56: 417-450, 2001.

61. Farnworth PG, Stanton PG, Wang Y, Escalona R, Findlay JK and Ooi GT: Inhibins differentially antagonize activin and bone morphogenetic protein action in a mouse adrenocortical cell line. Endocrinology 147: 3462-3471, 2006.

62. Makanji Y, Harrison CA, Stanton PG, Krishna R and Robertson DM: Inhibin A and $\mathrm{B}$ in vitro bioactivities are modified by their degree of glycosylation and their affinities to betaglycan. Endocrinology 148: 2309-2316, 2007.

63. Hempel N, How T, Dong M, Murphy SK, Fields TA and Blobe GC: Loss of betaglycan expression in ovarian cancer: role in motility and invasion. Cancer Res 67: 5231-5238, 2007.

64. Dong M, How T, Kirkbride KC, et al: The type III TGF-beta receptor suppresses breast cancer progression. J Clin Invest 117: 206-217, 2007

65. Gordon KJ and Blobe GC: Role of transforming growth factorbeta superfamily signaling pathways in human disease. Biochim Biophys Acta 1782: 197-228, 2008.

66. Gordon KJ, Dong M, Chislock EM, Fields TA and Blobe GC: Loss of type III transforming growth factor beta receptor expression increases motility and invasiveness associated with epithelial to mesenchymal transition during pancreatic cancer progression. Carcinogenesis 29: 252-262, 2008.
67. Criswell TL, Dumont N, Barnett JV and Arteaga CL: Knockdown of the transforming growth factor-beta type III receptor impairs motility and invasion of metastatic cancer cells. Cancer Res 68: 7304-7312, 2008

68. Farnworth PG, Wang Y, Escalona R, Leembruggen P, Ooi GT and Findlay JK: Transforming growth factor-beta blocks inhibin binding to different target cell types in a context-dependent manner through dual mechanisms involving betaglycan. Endocrinology 148: 5355-5368, 2007.

69. Steller MD, Shaw TJ, Vanderhyden BC and Ethier JF: Inhibin resistance is associated with aggressive tumorigenicity of ovarian cancer cells. Mol Cancer Res 3: 50-61, 2005.

70. Hoeing A, Kuhn C, Shabani N, et al: The immunohistochemical expression of the inhibin/activin subunits is up-regulated by interferon-beta1a in Ishikawa cell line. Anticancer Res 27: 2005-2010, 2007.

71. Vogl J, Hoing A, Schulze S, et al: Expression of inhibins in the endometrial carcinoma cell line RL-95-2 after stimulation with cortisol and estradiol. Anticancer Res 27: 1989-1993, 2007.

72. Burdette JE and Woodruff TK: Activin and estrogen crosstalk regulates transcription in human breast cancer cells. Endocr Relat Cancer 14: 679-689, 2007. 